\title{
CRITICAL SUCCESS FACTORS OF PARTNERING IN THE BUILDING DESIGN PROCESS
}

\author{
Sevgi Zeynep DOĞAN*, Pınar KILIÇ ÇALĞICI*, \\ David ARDITI**, Hüsnü Murat GÜNAYDIN***
}

Received: 18.06.2014; Final Text: 01.10.2015

Keywords: Partnering; design process; success factors; factor analysis; multiple regression analysis.

\footnotetext{
* Department of Architecture, İzmir Institute of Technology, İzmir, TURKEY.

** Department of Civil, Architectural and Environmental Engineering, Illinois Institute of Technology, Chicago, USA.

*** Department of Architecture, İstanbul Technical University, İstanbul, TURKEY.
}

\section{INTRODUCTION}

The construction industry is vertically fragmented because of the inherent nature of construction projects, which require planning, design, letting, construction, and operation in distinct phases (Fellows and Liu, 2012; Fong and Lung, 2007). The construction industry is also horizontally fragmented because of the general tendency of participants to work independently in all phases of the project (Fellows and Liu, 2012; Saram and Ahmed, 2001). Given the increasing number of construction projects in the current global environment, geographical fragmentation is caused by project participants that are frequently geographically separated. The construction industry is also temporally fragmented, as the phases of construction projects diverge over an estimated time period (Luck, 1996). According to Evbuomwan and Anumba (1998), the fragmentation in the industry results in costly engineering changes and design iterations, time and cost increases, poor communication between project participants, neglect of the application of sustainability principles throughout the life cycle of the building, and inadequate coordination and integration of the various participants. The root cause of much of these problems encountered in the management of building projects can be traced back to the design phase.

The building design process typically involves the participation of architects, engineers (structural, mechanical, electrical, and environmental engineers) and material suppliers. In some project delivery systems, contractors are also involved in the design process. The lack of effective coordination among different disciplines in the building design process may affect not only the design but also the construction processes and the final product, creating problems related to schedule, quality, manpower, materials used, and cost. The interaction of the project participants is vital for the success of the project. Architects and engineers must recognize the collaborative nature of the building design process and support 
the effective management of the design tasks carried out by different professionals.

Partnering provides an integrative, coordinated approach by bringing the various design participants together at the beginning of the design phase and is expected to diminish the problems caused by fragmentation, such as lack of coordination and integration and the resultant conflicts (Fellows and Liu, 2012; Weingardt, 1996). The origins of the partnering concept can be found in the Japanese management strategy Kaizen, which emerged after the end of World War II (Imai, 1986). Like Kaizen, partnering focuses on the importance of process, in which all parties have commitment, rather than a top-down approach (Imai, 1986). Lawrence and Lorsch's (1967) empirical work proved that to achieve organizational goals, firms should have a balance between high differentiation (i.e., specialization in architecture, structural engineering, environmental science, electrical and mechanical systems, etc.) and integration (i.e., some sort of partnering). The work of Bennett and Jayes (1998) is of particular importance because it identified the most important factors in successful partnering between the client and all other parties in the construction process; this information was later adopted and promoted in the Egan Report (Egan, 1998), which is credited with the significant efficiency improvements that subsequently took place in the UK construction industry. In the literature on partnering, research generally focuses on partnering in the context of construction companies and construction owners (e.g., Black et al., 2000; Chan et al., 2004; Tang et al., 2006; Fisher and Green, 2001). However, design offices also use partnering and consider it desirable for successful and feasible designs (Weingardt, 1996). This study focuses on partnering in the design phase of building projects.

There are numerous definitions of partnering in the literature. Most of them state that partnering is a form of teamwork and refer to collaborative approaches in which all participants agree to give their best to complete the project successfully for the users' benefit. According to Liu and Fellows (2001), Chan et al. (2004), and Nyström (2005), partnering is based on mutual trust, common goals, commitment, and effective communication. Regarding the competitive nature of the construction industry, Abudayyeh (1994), Larson (1995) and Fong and Lung (2007) claim that partnering aims to resolve problems between the participants, transform confrontational relationships into cooperative ones, establish continuous development, provide on-time and within-budget delivery, enhance communication, increase the quality of the product and provide better customer satisfaction. However, evidence in favor of partnering is not always convincing. Although there have been fewer indications of the failure of partnering to meet performance expectations, these are by no means absent (CII, 1994; Rackham et al., 1996; Angelo, 1998). Green and McDermott (1996) state that the use of partnering does not necessarily lead to effective outcomes, just as traditional forms of contracting do not necessarily result in poor performance. Bresnen and Marshall (2000b) argue that there is still a need for more systematic and in-depth research that examines the nature, efficacy, and feasibility of a partnering approach.

Several researchers have studied, defined and discussed the critical success factors of partnering in construction (e.g., Black et al., 2000; Cheng et al., 2000; Chan et al., 2004; Tang et al., 2006; Chen and Chen, 2007). Critical success factors may be controversial, as they can be affected by local culture and practices. Nevertheless, mutual trust, effective communication, 
1. See the seven papers presented at a symposium organized by the Federal Construction Council (1994), Weingardt (1996), Van der Merwe and Basson (2013)

2. See the 133 papers investigated by Hong et al. (2012) support from top management, clearly defined responsibilities, mutual goals, a dedicated team, commitment to continuous improvement and a win-win attitude are considered to be the most cited critical success factors in these studies. These success factors have been investigated in the context of construction companies and construction owners and are valid in the construction phase of building projects. However, research on partnering in the building design process has been minimal, as evidenced by the handful of papers published related to design (1) as opposed to the multitude of papers published related to construction (2). In effect, bypassing the design phase in partnering research marginalized the important role that architects play in the building production process. The scarcity of partnering studies regarding architects and the design phase is unfortunate. The main contribution of this study is that it addresses this relatively unexplored research area. Considering the multidisciplinary and collaborative character of the building design process, this paper focuses on exploring the critical success factors of partnering in the building design process.

\section{METHODS}

The empirical part of this research centers on administering a questionnaire survey to practicing architects and using statistical methods, drawing conclusions about critical success factors related to partnering in the design process. Using a questionnaire is a standard method of data collection that is practical, cost-effective, less intrusive than telephone or face-to-face interviews and anonymous. The questionnaire was prepared with the help of the literature on critical success factors in partnering practices. As a result, efficient communication (Moore et al., 1992; Mohr and Spekman, 1994; Hellard, 1996; Black et al., 2000; Cheng et al., 2000; Chan et al., 2004; Tang et al., 2006), effective coordination (Mohr and Spekman, 1994; Cheng et al., 2000; Bayramoğlu, 2001; Chan et al., 2004), mutual objectives (Bennet and Jayes, 1998; Chan et al., 2004; Tang et al., 2006), common goals (Hardback et al., 1994; Mohr and Spekman, 1994; Brooke and Litwin, 1997), long-term relationships (Mohr and Spekman, 1994; Black et al., 2000; Bresnen and Marshall, 2000a; Cheng et al., 2000; Chan et al., 2004), mutual trust (Hardback et al., 1994; Mohr and Spekman, 1994; Hellard, 1996; Black et al., 2000; Cheng et al., 2000; Chan et al., 2004; Tang et al., 2006), and management support (Harback et al., 1994; Hellard, 1996; Cheng et al., 2000; Chan et al., 2004) were investigated.

First, a pilot study was conducted by soliciting the perspectives of 10 practicing professional architects. These architects were not selected using a sampling process that involved geographical distribution, size of firm, commercial vs. residential design or any such criterion; they were selected purely on the basis of personal acquaintance and appreciation for their status in the design field. The purpose of piloting the questionnaire was to improve the questionnaire's internal validity. It was conducted to ascertain that the responses could be interpreted using the information sought. Depending on the feedback of the respondents, some of the questions were eliminated, re-worded, and/or re-scaled. Hence, the questionnaire was refined based on the input received in the pilot study and was used in the final survey. The survey was administered to 104 practicing professional architects in İzmir, Turkey. Factor analysis and multiple regression analysis were used to analyze the data collected and to draw conclusions. 
The questionnaire consisted of two parts. The first part included four questions about participants' professional experience, frequency of partnering in the design process, volume of work done per year and the professions/trades represented by the partners. The second part of the questionnaire included 29 statements about partnering practices, and the respondents were asked to respond on a five-point Likert format (1: strongly disagree to 5 : strongly agree) based on their partnering experience in the design process. A five-point scale was selected because the participants in the pilot survey were able to discriminate between the alternatives quite comfortably. The survey was administered to the participants of a seminar organized by the İzmir Branch of the Turkish Chamber of Architects. According to this organization, there were 850 design firms in İzmir, the primary target population at the time the study was performed. The 125 architects who attended this seminar were requested to respond to the questionnaire survey but only 104 of them responded, resulting in a response rate of $83 \%$. Assuming that the respondents represent their respective design firm, the 104 architects who participated in the study represent $12 \%$ of the 850 design firms in İzmir.

The statistical analysis techniques used included factor analysis and multiple regression analysis. Factor analysis is a statistical technique used to identify a relatively small number of factors that can be used to represent relationships among a set of many interrelated variables (Norusis, 1993). A regression model is a mathematical model that can relate a number of independent variables to a dependent variable (Norusis, 1993). Factor analysis was used to identify the underlying dimensions of partnering success and multiple regression analysis was used to seek the strongest predictors of partnering success. The analyses were conducted using the SPSS 15 (IBM Inc., 2007) software package.

\section{FINDINGS}

The findings of the first part of the questionnaire provided descriptive statistics:

- Most participants (96\%) had 10 or more years of professional experience.

- Most participants frequently partnered in their design practice. Ninety-four percent marked "always" or "often" rather than "sometimes", "seldom" or "never".

- The participants were involved in $20.000-250.000 \mathrm{~m}^{2}$ of building construction per year.

- The participants collaborated with civil, mechanical, electrical engineers and clients.

\section{Factor Analysis Results}

Exploratory factor analysis employing principal component analysis with the varimax rotation method was used to determine the factors leading to partnering success. As per Kline's (1994) recommendation, exploratory factor analysis was used instead of confirmatory factor analysis because the factor analysis in this research was meant primarily not to test an established factor structure but to develop a factor structure classifying the elements leading to partnering success. Prior to factor analysis, the adequacy of the sample and the data were tested using the procedures 
recommended by Hair et al. (2006). The Kaiser-Meyer-Olkin (KMO) measure of sampling adequacy was used to test the sample. Barlett's test of sphericity was conducted to determine whether the data matrix used in this analysis was appropriate for factor analysis. The KMO statistic had a value of 0.842 , which is greater than the minimum threshold of 0.50 recommended by Norusis (1993). The p-value for Bartlett's test of sphericity was 0.001 . Additionally, although opinions among researchers differ, Kline (1994) recommends that the sample size should not be less than 100 subjects and that the subject-to-variable ratio should not be less than 2.0 for good results in factor analysis. The sample in this study was composed of 104 architects, and the subject-to-variable ratio was 104/28=3.7, satisfying both recommendations. Hence, the sample size and the data matrix were fairly appropriate for factor analysis.

Principal component analysis with varimax rotation was carried out for factor extraction in order to decide the number of factors to be retained. Using principal component analysis, the items in the data set were reduced into a smaller number of factors, i.e., the potential underlying factors of partnering success. Table 1 presents the factor loadings as well as the percentage and cumulative percentage of the variance explained by the factors. The factor loadings in Table 1 indicate the extent to which each of the variables contributes to the meaning of the factors. As per Field's (2000) recommendation, a threshold of 0.40 was used, implying that only variables with a factor loading of 0.40 or higher were retained to define a factor. The information under the heading "Percent Variance Explained" in Table 1 indicates how much of the variance in all observed variables is due to a given factor. The last column in Table 1 shows that the seven factors that were extracted cumulatively accounted for $62 \%$ of the total variance in the data. Values ranging from $40 \%$ to $60 \%$ are considered acceptable in social studies (Dunteman, 1989).

Efficient Communication $\left(\mathrm{X}_{1}\right)$ : Factor 1 consists of eight items and accounts for approximately $15 \%$ of the variance. The items are related to effective communication strategies and enhancing communication between design team members for the streamlining of the building design process by sharing mutual goals and avoiding adversarial relationships among collaborators.

Effective Coordination $\left(\mathrm{X}_{2}\right)$ : Factor 2 consists of three items and accounts for approximately $10 \%$ of the variance. The items focus on effective coordination in the design process, including coordination among the collaborators, conflict resolution strategies, and the collaborators' willingness to share information for the benefit of the design process.

Mutual Objectives $\left(X_{3}\right)$ : Factor 3 consists of four items and accounts for approximately $8 \%$ of the variance. The items are related to clearly defining mutual objectives, responsibilities, and tasks in a participative manner for the benefit of the design process. This focus on mutual objectives (i.e., structural and architectural plan compatibility) in the short term supports the attainment of common goals (i.e., building performance in terms of quality, cost, and time) in the long term.

Common Goals $\left(\mathrm{X}_{4}\right)$ : Factor 4 consists of five items and accounts for approximately $8 \%$ of the variance. The items are related to identifying common goals, taking responsibility for project goals, resolving conflicts amicably, and eliminating communication barriers to achieving goals. 


\begin{tabular}{|c|c|c|c|}
\hline Factors & $\begin{array}{l}\text { Factor } \\
\text { Loading }\end{array}$ & $\begin{array}{l}\text { Percent of } \\
\text { variance } \\
\text { explained }\end{array}$ & $\begin{array}{c}\text { Cumulative } \\
\text { variance } \\
\text { explained } \\
\end{array}$ \\
\hline $\begin{array}{l}\text { Q1: My collaborators work for mutual goals, are inclusive, and avoid a competitive } \\
\text { posture }\end{array}$ & 0.70 & & \\
\hline Q17: My collaborators always inform me about changes in the architectural design & 0.66 & & \\
\hline Q8: My collaborators have effective communication strategies & 0.64 & & \\
\hline $\begin{array}{l}\text { Q26: My collaborators are willing to eliminate barriers to the improvement of the } \\
\text { architectural design process }\end{array}$ & 0.61 & & \\
\hline $\begin{array}{l}\text { Q14: We always have meetings to improve communication in the architectural design } \\
\text { process }\end{array}$ & 0.60 & & \\
\hline $\begin{array}{l}\text { Q19: I provide constructive criticism on my collaborators' decisions about the } \\
\text { architectural design }\end{array}$ & 0.58 & & \\
\hline Q3: My collaborators always help me when I need information about the project & 0.57 & & \\
\hline $\begin{array}{l}\text { Q28: My collaborators do not take a combative posture to gain an advantage during the } \\
\text { architectural design process }\end{array}$ & 0.51 & & \\
\hline Factor $1\left(X_{1}\right)$ : Efficient communication & & $15 \%$ & $15 \%$ \\
\hline Q13: My collaborators' activities are always coordinated & 0.76 & & \\
\hline $\begin{array}{l}\text { Q25: I have a strategy that allows me to deal with obstacles to effective coordination in } \\
\text { architectural design }\end{array}$ & 0.73 & & \\
\hline Q2: My collaborators are willing to share information about design & 0.49 & & \\
\hline Factor $2\left(X_{2}\right)$ : Effective coordination & & $10 \%$ & $25 \%$ \\
\hline Q12: We always define mutual objectives during the architectural design process & 0.68 & & \\
\hline $\begin{array}{l}\text { Q20: Our problems in the architectural design process are always solved in a timely and } \\
\text { responsive manner }\end{array}$ & 0.65 & & \\
\hline $\begin{array}{l}\text { Q15: Division of labor and responsibilities are clearly defined in the architectural design } \\
\text { process }\end{array}$ & 0.58 & & \\
\hline Q27: All collaborators are willing to share resources and ideas & 0.53 & & \\
\hline Factor $3\left(\mathrm{X}_{3}\right)$ : Mutual objectives & & $8 \%$ & $33 \%$ \\
\hline Q21: I am willing to bear joint responsibility for design issues & 0.63 & & \\
\hline Q7: I am willing to resolve my differences with collaborators amicably & 0.58 & & \\
\hline Q11: My goals are aligned with my collaborators' goals & 0.51 & & \\
\hline Q24: I fulfill my responsibilities and satisfy my collaborators' expectations & 0.51 & & \\
\hline $\begin{array}{l}\text { Q16: I do not have any communication problems that may obstruct the achievement of } \\
\text { goals }\end{array}$ & 0.47 & & \\
\hline Factor $4\left(\mathrm{X}_{4}\right)$ : Common goals & & $8 \%$ & $41 \%$ \\
\hline Q22: I do not want to develop a long-term partnering process with my collaborators (R) & 0.71 & & \\
\hline $\begin{array}{l}\text { Q9: My collaborators are not interested in developing harmonious relationships to } \\
\text { support a project's objectives }(\mathrm{R})\end{array}$ & 0.65 & & \\
\hline $\begin{array}{l}\text { Q4: My collaborators always act based on self-interest rather than promoting the } \\
\text { project's goals }(\mathrm{R})\end{array}$ & 0.54 & & \\
\hline Factor $5\left(\mathrm{X}_{5}\right)$ : Long-term relationships & & $7 \%$ & $48 \%$ \\
\hline Q23: Partnering is established at the beginning of the architectural design phase & 0.78 & & \\
\hline Q6: I believe that it is important to establish mutual trust among collaborators in a project & 0.50 & & \\
\hline $\begin{array}{l}\text { Q18: I trust that my collaborators' decisions are very useful for the improvement of the } \\
\text { architectural design process }\end{array}$ & 0.48 & & \\
\hline Factor $6\left(\mathrm{X}_{6}\right)$ : Mutual trust & & $7 \%$ & $55 \%$ \\
\hline $\begin{array}{l}\text { Q10: I provide enough resources, budget, labor, time, and authority for a smooth } \\
\text { partnering agreement }\end{array}$ & 0.80 & & \\
\hline Q5: Every manager in our design office is willing to support the partnering process & 0.73 & & \\
\hline Factor $7\left(\mathrm{X}_{7}\right)$ : Management support & & $7 \%$ & $62 \%$ \\
\hline
\end{tabular}

Table 1. Factor Structure of the Partnering Success Factor Items

Note: (R): Recoded for factor analysis as a reverse scale (5 to 1 ) instead of (1 to 5) 
Long-term Relationships $\left(X_{5}\right)$ : Factor 5 consists of three items and accounts for approximately $7 \%$ of the variance. Factor 5 is related to destructive behaviors such as preferring short-term agreement, not seeking harmonious relationships to achieve common objectives, and putting self-interest first and project objectives second. The items of Factor 5 offered negative statements that do not benefit the design process and that constitute barriers against a win-win environment. The 1-5 scoring was reversed to a 5-1 scoring before this variable was included in the regression analysis.

Mutual Trust $\left(X_{6}\right)$ : Factor 6 consists of three items and accounts for approximately $7 \%$ of the variance. Having a relationship based on trust and a belief that does not suspect unfair or fraudulent activity on the part of the collaborators from the beginning of the design process constitutes the items in Factor 6.

Management Support $\left(\mathrm{X}_{7}\right)$ : Factor 7 consists of two items and accounts for approximately $7 \%$ of the variance. The items are related to the support provided by managers for a smooth partnering arrangement.

\section{Regression Analysis Results}

Multiple regression analysis was conducted to determine the relative significance of the factors that were extracted from factor analysis. The seven factors were set up as independent variables and were labeled $X_{1}$ to $X_{7}$. The participants' personal perception of partnering success was taken as the dependent variable and was labeled Y. The dependent variable was measured by participants' rating of the following statement: My collaborators always derive great satisfaction from partnering with me. This variable represents a respondent's perception of partnering success by assessing how satisfied the other parties are with the partnering arrangement. The dependent variable could be formulated by an egocentric or a perspective-taking model, as defined by Steins (2000). According to Steins (2000), the main motivation for a perspective-taking model is the intensity of the relationship between the perceiver and the perceived persons. The respondents in the study were challenged to give nonegocentric responses to the question because the many parties involved in the design process have great impact on the work of designers, the designers' ego and prestige and the expectation of further contracts.

Table 2 presents the results of the multiple regression analysis. Because the significance level was 0.001 ( $p \leq 0.001)$ with an F value of 13.57, the regression model was statistically significant. According to Bryman and Cramer (2005), the coefficient of determination, $R^{2}$, is a measure of the predictive capability of model. It indicates how well the dependent variable can be predicted using the independent variables. It takes values ranging from 0 to 1 . In other words, $R^{2}$ indicates the proportion of variance explained by the regression model (Berry and Feldman, 1985). However, $\mathrm{R}^{2}$ can sometimes be misleading because it always increases as variables are added to the equation even when they have no effect on the dependent variable (Berry and Feldman, 1985). To avoid this problem, both $\mathrm{R}^{2}$ and adjusted $\mathrm{R}^{2}$ were computed. Unlike $\mathrm{R}^{2}$, adjusted $\mathrm{R}^{2}$ does not always increase as variables are added to the regression model. The adjusted $\mathrm{R}^{2}$ was found to be 0.46 , which means that the regression model explained $46 \%$ of the variability in the participants' perception of success. Because all tolerance values are greater than 0.2 and the variance inflation factor (VIF) is less than 10 (Table 2), there was no multicollinearity problem 


\begin{tabular}{|c|c|c|c|c|c|}
\hline $\begin{array}{l}\text { Independent } \\
\text { Variable } \\
\text { (Underlying } \\
\text { Success Factor) }\end{array}$ & $\begin{array}{c}\text { Standardized } \\
\text { Coefficient } \\
(\beta)\end{array}$ & $\mathrm{t}$ value & $\begin{array}{c}\text { Significance } \\
\text { Level }(p)\end{array}$ & $\begin{array}{l}\text { Collinearity } \\
\text { Statistics }\end{array}$ & $\begin{array}{c}\text { Tolerance } \\
\text { VIF }\end{array}$ \\
\hline $\begin{array}{l}\text { Variable } \mathrm{X}_{1} \\
\text { Efficient } \\
\text { communication }\end{array}$ & 0.104 & 0.940 & 0.350 & 0.424 & 2.356 \\
\hline $\begin{array}{l}\text { Variable } \mathrm{X}_{2} \\
\text { Effective } \\
\text { coordination }\end{array}$ & 0.473 & 4.710 & $0.001 *$ & 0.520 & 1.925 \\
\hline $\begin{array}{l}\text { Variable } \mathrm{X}_{3} \\
\text { Mutual objectives }\end{array}$ & 0.117 & 1.206 & 0.231 & 0.558 & 1.792 \\
\hline $\begin{array}{l}\text { Variable } \mathrm{X}_{4} \\
\text { Common goals }\end{array}$ & 0.237 & 2.551 & $0.012^{*}$ & 0.607 & 1.646 \\
\hline $\begin{array}{l}\text { Variable } \mathrm{X}_{5} \\
\text { Long-term } \\
\text { relationships }\end{array}$ & 0.183 & 2.214 & $0.036^{*}$ & 0.708 & 1.411 \\
\hline $\begin{array}{l}\text { Variable } X_{6} \\
\text { Mutual trust }\end{array}$ & 0.009 & 0.107 & 0.915 & 0.672 & 1.488 \\
\hline $\begin{array}{l}\text { Variable } X_{7} \\
\text { Management } \\
\text { support }\end{array}$ & 0.007 & 0.083 & 0.934 & 0.659 & 1.518 \\
\hline
\end{tabular}

Note: ${ }^{*} p \leq 0.05$

in the regression model. To determine the most effective independent variables on partnering success, the $\beta$ coefficients of the independent variables and their significance levels were computed. The $\beta$ coefficients of the independent variables indicated positive relationships between the dependent and independent variables. Only variables $X_{2}, X_{4}$ and $X_{5}$ were statistically significant because the computed significance levels of $\beta_{2}, \beta_{4}$ and $\beta_{5}$ were lower than $0.05(\mathrm{p}<0.05)$. After conducting factor and multiple regression analyses, the strongest predictors of partnering success were found to be (1) effective coordination, (2) common goals, and (3) long-term relationships. Figure 1 summarizes the results of the data analysis.

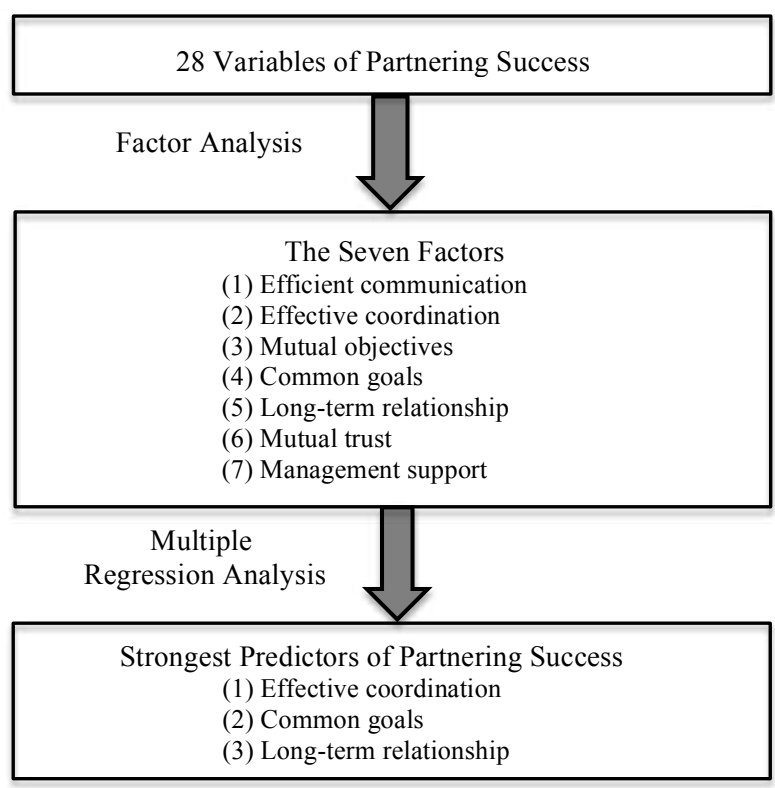




\section{DISCUSSION}

The discussion in this paper revolves around some unresolved or neglected issues in the literature related to the potential conflict between architects and other participants in the design phase and the inherent difficulties in attempting to make design decisions under collaborative approaches.

\section{Effective Coordination}

The factor that was found to be most important for partnering success in the design phase was effective coordination. Because the building design process is fragmented by the nature of the different professions represented in the process (e.g., architects, structural, mechanical, electrical, environmental engineers, etc.) the design team is expected to experience deficiencies in coordination. Coordination refers to specific protocols and procedures in conjunction with a smooth flow of communication in all directions to achieve project objectives (Chitkara, 1998). Technical interdependency and organizational independency in building design demand an effective coordination process that facilitates information flow. Most researchers agree that effective coordination between the participants of the design process is important for partnering success (e.g., Ronco and Ronco, 1996; Cheng et al., 2000; Chan et al., 2004). Coordination between designers and constructors is crucial in the construction process as well (Saram and Ahmed, 2001).

The quality of coordination affects overall project performance and productivity (Zaneldin et al., 2001; Hegazy et al., 2001). It is therefore not surprising that respondents identified effective coordination as the most important critical success factor of partnering. The consequences of severe design coordination problems include a large number of change orders and numerous disagreements, claims, and disputes, which in turn lead to delays, cost overruns, and overall owner dissatisfaction. Given the multicollaborator environment of the design process and the owner-imposed time and cost constraints on the design firm, coordination-related errors in design documents are difficult to control, particularly in large and complex building projects (Tilley and Barton, 1997; Mokhtar et al., 1998). Many of these errors and constructability problems are not discovered until during construction, requiring costly solutions that may cause significant delay.

Effective coordination is a key challenge for project participants in achieving the required project performance and productivity. Recent studies have focused on exploring various mechanisms to improve coordination (Weick et al., 2005; Vargo and Lusch, 2008; Fellows and Liu, 2012; Owen, 2012). Improving coordination starts with understanding and measuring it, but it is an abstract concept that is difficult to measure. Coordination is typically assessed using qualitative methods such as identifying those participants who display dominant roles or using complex approaches, e.g., the approach developed by Malone and Crowston (1994) that measures the effectiveness of coordination through an assessment of the management of shared resources, simultaneity constraints, collaborators' relationships, and task dependencies. Effective coordination can be achieved by using recently developed approaches such as sensemaking, i.e., creating shared awareness and understanding out of different project participants' perspectives, experiences, and varied interests (Weick et al., 2005); co-creation, i.e., creating joint value through shared inventiveness, shared information, and shared interests 
(Vargo and Lusch, 2008); boundary management, i.e., recognizing mutual interdependence and, hence, commitment and collaborative behavior by adjusting demarcations of cultures, climates, knowledge, practices and resources (Fellows and Liu, 2012); and novel project delivery systems such as AIA's Integrated Project Delivery (IPD) (AIA, 2007) and CIB's Integrated Design and Delivery Solutions (IDDS) (Owen, 2012), i.e., harnessing the talents and insights of all project participants to optimize project results, increase value, reduce waste, and maximize efficiency by integrating people, systems, business structures and practices.

In this research on the design phase, the factor that was found to be most important for partnering success was effective coordination; however, in previous studies regarding the construction phase, the important factors affecting partnering success were mutual trust and efficient communication (e.g., Black et al., 2000; Cheng et al., 2000; Chan et al., 2004; Tang et al., 2006). This discrepancy can be explained by Yuan et al.'s (2009) and Aral et al.'s (2008) argument that effective coordination cannot be achieved unless there is efficient communication and mutual trust. Therefore, this finding implies that trust and communication affect partnering success indirectly via coordination.

\section{Common Goals}

The second most important factor of partnering success in the design phase was common goals. Common goals direct efforts toward goal-relevant activities and away from perceived undesirable actions. Individual goals create competitive behavior, while shared goals are the glue holding a relationship together in times of stress. Developing common goals enables firms to eliminate non-value-added activities, reduce waste and duplication, establish clarity of responsibility, resolve conflicts before they develop into disputes, and improve processes (Harback et al., 1994; Crowley and Karim, 1995; DeVilbiss and Leonard, 2000; Liu and Fellows, 2001; Chan et al., 2004; Nyström, 2005; Tang et al., 2006). Fox (1974) indicates that persons who share common goals are capable of allocating roles among themselves in light of what they perceive as "functional necessities." Quinn and Dutton (2005) describe common goals as the provider of the energy and emotion for the effective coordination of work. Consistent with this observation, others have identified common goals as playing an important role in enabling parties to accomplish a set of interdependent tasks and facilitate effective coordination (Saavedra et al., 1993; Wageman, 1995). Therefore, mechanisms underlying effective coordination (i.e., sensemaking and co-creation) are indeed integral to common goal development.

The maintenance of harmony and the resolution of conflicts between parties are difficult in the multi-participant environment of partnering in the building design process if individual goals dominate and disturb the balance of shared goals between participants. Thus, underdeveloped common goals cause the design team to experience difficulty in taking joint responsibility for problematic issues.

\section{Long-term Relationships}

The third and final most important predictor of partnering success in the building design process was long-term relationships. The firms participating in the design process are interdependent, as they are embedded in a complex and dynamic organization. Each firm is influenced by other firms with which it must transact. However, this organization is 
not permanent. It is bound by both contractual conditions and information exchange between the different participants, but it typically disbands after the project is completed. According to Black et al. (2000), construction project stakeholders rate short-term focus as one of the most damaging aspects of partnering. According to Constructing Excellence (2004), partnering can be project-specific or can cover a number of projects, but long-term partnering is considered to provide greater opportunity for improvement. Bennett and Jayes (1998) assert that an explicit long-term strategy can generate significant improvements in performance over several years and over a number of projects. However, Bennett and Jayes (1998) also emphasize that improvements in partnering can only be captured if firms possess good partnering skills. A focus on long-term relationships helps to reduce adversarial relationships and disagreements between collaborators (Albanese, 1994), whereas in short-term relationships, partnering may lead to failure because the mutual accountability that grows naturally from working together for a long time with a common purpose was never established or was established too late after the design phase of the project (Albanese, 1994; Anvuur and Kumaraswamy, 2007).

\section{CONCLUSION}

The multi-dimensional fragmentation in the building design process presents special challenges to design participants. The successful management of these challenges requires the harmonious regulation of the demands of the various disciplines involved in the design phase. Partnering is a process that is expected to reconcile the conflicting demands of the participants in performing design tasks.

This study investigated the key factors of a successful partnering arrangement between the professionals involved in building design. Seven factors were extracted from the 27 original variables by conducting factor analysis on data collected from 104 architects in İzmir, Turkey. Multiple regression analysis was conducted to find the factors that most affected successful partnering. The findings indicate that successful partnering in building design requires, 1) pursuing effective coordination by promoting strategies that can prevent a chaotic design process and by encouraging collaborators to voluntarily share information, 2) recognizing and establishing common goals by aligning one's goals to fulfill collaborators' expectations, by communicating efficiently and by resolving differences between collaborators amicably, and 3) encouraging long-term, harmonious relationships among collaborators in the design process by promoting the project's goals over an individual party's self-interest.

At first glance, the three factors that this study found most significant are somewhat obvious, as evidenced by the success factors of partnering that are reported extensively in the literature. For example, according to Higgin and Jessop (1965) and Bennett and Jayes (1995), there is a fairly wide consensus over the basic philosophy underpinning partnering, namely, that partnering success depends upon improving the quality of relations between participants, encouraging feedback and mutual adjustment between the parties, and nurturing a commitment between partnering parties to cooperate. However, thus far, the literature has primarily focused on the partnering between construction owners and contractors (Bresnen and Marshall, 2000b), while investigating the success factors of partnering during the design phase remains an unexplored research area. One of the 
contributions of this study is that it identifies the critical success factors of partnering solely during building design activity.

This study indicates that architects believe a number of barriers exist that prevent successful partnering in the design phase. Thus, architects strongly emphasize the technical interdependency of the design project by seeking effective coordination; they appreciate the full commitment of all collaborators to the final design product by focusing on common goals; and, finally, they seek commitment to the design process by emphasizing long-term relationships to encourage cooperation in the design process. In line with the views of Turkish architects, the Integrated Project Delivery system that is highly acclaimed by the American Institute of Architects (AIA, 2007) also relies on the basic principles of effective coordination, the pursuit of common goals, and long-term relationships in all phases of a building project, including the design phase. Similarly, the Integrated Design and Delivery Solutions (IDDS) proposed by the International Council for Research and Innovation in Building and Construction (CIB, 2014) emphasizes that elimination of traditionally adversarial relationships inevitably leads to significant added value in coordinating the activities of designers, thus creating a cooperative and sharing construction industry instead of one characterized by adversarial interactions and knowledge hoarding. Finally, the findings of this study are in line with Charleson and Pirie's (2009) findings as well; this study also encourages self-reflection for design collaborators, particularly in terms of (1) pursuing effective coordination, (2) recognizing and establishing common goals, and (3) encouraging long-term, harmonious relationships among collaborators in the design process. Thus, enhanced relationships among the participants of the building design process are expected to contribute to the welfare of the construction industry, which often suffers from frequent and costly litigation.

The findings of this study are of significance for educators as well as practitioners. In terms of education, the findings are of importance in curricular matters, particularly in the organization of architecture design studios and engineering design classes. Architecture students could improve their professional and technical talents by teaming up with structural, mechanical and electrical engineering students; thus, they would learn how to partner with them by coordinating their activities effectively, recognizing that they are all working towards common goals, and establishing harmonious and cohesive relationships. The same can be said for engineering students. Including targeted training in architecture and engineering curricula and exposing future designers to the type of inter-professional problems that they may face in practice may contribute favorably to establishing strong partnering practices in the design process in the long run. Educators in architecture and engineering, regardless of where they are located in the world, should take note of this study and adjust their curricula accordingly.

For practitioners, assuming that they have not been through the sort of education mentioned in the preceding passage, the practical implications of the findings include practitioners' recognition of the important factors that may lead to strong partnering. If they are sensitized to these issues, designers are expected to break with tradition and put the interests of the project above their own firm's self-interest, voluntarily exchange technical and managerial information with their collaborators rather than providing limited information only when asked, take joint responsibility for design 
issues, resolve disagreements between collaborators in a mutually agreeable way, and establish solid and long-lasting relationships with collaborators. Successful partnering requires recognizing these critical success factors that were identified in this study.

Given the display of self-interest, individualism, fragmentation, and opportunistic behavior that can be currently observed during the design process, partnering appears to be a feasible solution to this situation in the long run. However, partnering in the design process has never been formally explored before. This study promotes strong partnering practices in the current fragmented environment. The recommendations of the study include establishing effective coordination between collaborators and encouraging all collaborators to pursue common goals and to seek long-term, harmonious relationships. These recommendations can be used to adjust architecture and engineering curricula to prepare future professionals for the design professions and to encourage practitioners to recognize these issues in order to achieve strong partnering among design collaborators. Further studies should involve recording the perceptions of other collaborators (i.e., engineers and clients) and identifying similarities and differences between different collaborators' perceptions.

\section{REFERENCES}

ABUDAYYEH, O. (1994) Partnering: A Team Building Approach to Quality Construction Management, Journal of Management in Engineering 10(6) 26-9.

AIA (American Institute of Architects) (2007) Integrated Project Delivery: A Guide, AIA, Washington, DC.

ALBANESE, R. (1994) Team-Building Process: Key to Better Project Results, Journal of Management in Engineering 10(6) 36-44.

ANGELO, W.J. (1998) Partnering Goes Awry on Connecticut Bridge Job, Engineering News Record 240(18) 17.

ANVUUR, A.M., KUMARASWAMY, M.M. (2007) Conceptual Model of Partnering and Alliancing, Journal of Construction Engineering and Management 133(3) 225-34.

ARAL, S., BRYNJOLFSSON, E., VAN ALSTYNE, M. (2008) Antecedents and Consequences of Mutual Knowledge in Teams. The MIT Center for Digital Business: A Partnership in Research [ebusiness.mit. edu/research/papers/2008.11_Aral_Brynjolfsson_Van Alstyne_ Antecedents and Consequences_289.pdf] Access Date (09.01.2014).

BAYRAMOĞLU, S. (2001) Partnering in Construction: Improvement through Integration and Collaboration, Leadership and Management in Engineering 1(3) 39-43.

BENNETT, J., JAYES, S. (1995) Trusting the Team: The Best Practice Guide to Partnering in Construction, Centre for Strategic Studies in Construction, Reading Construction Forum, Reading, London.

BENNET, J., JAYES, S. (1998) The Seven Pillars of Partnering: A Guide to Second Generation Partnering, Thomas Telford, London.

BERRY, W.D., FELDMAN, S. (1985) Multiple Regression in Practice, Sage Publications, California. 
BLACK, C., AKINTOYE, A., FITZGERALD, E. (2000) An Analysis of Success Factors and Benefits of Partnering in Construction, International Journal of Project Management 18(6) 423-34.

BRESNEN, M., MARSHALL, N. (2000a) Motivation Commitment and the Use of Incentives in Partnerships and Alliances, Construction Management and Economics 18(5) 587-98.

BRESNEN, M., MARSHALL, N. (2000b) Partnering in Construction: A Critical Review of Issues, Problems and Dilemmas, Construction Management and Economics 18(2) 229-37.

BROKE, K.L., LITWIN, G.H. (1997) Mobilizing the Partnering Process, Journal of Management in Engineering 13(4) 42-8.

BRYMAN, A., CRAMER, D. (2005) Quantitative Data Analysis with SPSS 12 and 13, Taylor and Francis, London.

CHAN, A.P.C., CHAN, D.W.M., CHIANG, Y.H., TANG, B.S., CHAN, E.H.W., HO, K.S.K. (2004) Exploring Critical Success Factors for Partnering in Construction Projects, Journal of Construction Engineering and Management 130(2) 188-98.

CHARLESON, A.W., PIRIE, S. (2009) An Investigation of Structural Engineer-Architect Collaboration, Journal of the Structural Engineering Society New Zealand Inc. 22(1) 97-104.

CHEN, W.T., CHEN, T.T. (2007) Critical Success Factors for Construction Partnering in Taiwan, International Journal of Project Management 25(5) 475-84.

CHENG, E.W.L., LI, H., LOVE, P.E.D. (2000) Establishment of Critical Success Factors for Construction Partnering, Journal of Management in Engineering 16(2) 84-92.

CHITKARA, K.K. (1998) Construction Project Management: Planning, Scheduling and Controlling, Tata McGraw-Hill Publications, New Delhi.

CIB (International Council for Research and Innovation in Building and Construction) (2014) Integrated Design and Delivery Solutions Roadmap Summary, publication no. 373, [http://cibworld.xs4all.nl/dl/ publications/pub_373.pdf] Access Date (13.01.2014).

CII (Construction Industry Institute) (1994) Benchmarking Implementation Results, Teambuilding and Project Partnering, Austin, Texas.

Constructing Excellence (2004) Partnering. [http://www. constructingexcellence.org.uk/pdf/fact_sheet/partnering.pdf] Access Date (01.06. 2013).

CROWLEY, L.G., KARIM, A. (1995) Conceptual Model of Partnering, Journal of Management in Engineering 11(5) 33-9.

DEVILBISS, C.E., LEONARD, P. (2000) Partnering is the Foundation of a Learning Organization, Journal of Management in Engineering 16(4) 47-57.

DUNTEMAN, G.H. (1989) Principal Component Analysis: Quantitative Applications in the Social Sciences Series (Vol. 69), Sage Publications, Thousand Oaks, CA. 
EGAN, J. (1998) Rethinking Construction: Report of the Construction Task Force, HMSO, London.

EVBUOMWAN, N.F.O., ANUMBA, C.J. (1998) An Integrated Framework for Concurrent Life-Cycle Design and Construction, Advances in Engineering Software 29(7-9) 587-97.

FEDERAL CONSTRUCTION COUNCIL (1994) The Use of Partnering in the Facilities Design Process (Summary of a Symposium), Technical Report No. 126, National Academy Press, Washington DC.

FELLOWS, R., LIU, A.M.M. (2012) Managing Organizational Interfaces in Engineering Construction Projects: Addressing Fragmentation and Boundary Issues Across Multiple Interfaces, Construction Management and Economics 30(8) 653-71.

FIELD, A. (2000) Discovering Statistics Using SPSS for Windows, Sage Publications, London.

FISHER, N., GREEN, S. (2001) Partnering and the UK Construction Industry the First Ten Years: A Review of the Literature, Modernising Construction, ed. J. Boun, National Audit Office, London; 58-66.

FONG, P.S.W., LUNG, B.W.C. (2007) Interorganizational Teamwork in the Construction Industry, Journal of Construction Engineering and Management 133(2) 157-68.

FOX, A. (1974) Beyond Contact: Work Power and Trust Relations, Faber and Faber, London.

GREEN, C., MCDERMOTT, P. (1996) An Inside-Out Approach to Partnering, ESRC/EPSRC Workshop on Partnering in Construction, University of Salford, Manchaster.

HAIR, J.J., BLACK, W.C., BABIN, B.J., ANDERSON, R.E., TATHAM, R.L. (2006) Multivariate Data Analysis, Pearson Education, Upper Saddle River, New Jersey.

HARBACK, H.F., BASHAM, D.L., BUHTS, R.E. (1994) Partnering Paradigm, Journal of Management in Engineering 10(1) 23-7.

HELLARD, R.B. (1996) The Partnering Philosophy - A Procurement Strategy for Satisfaction through a Team Work Solution to Project Quality, Journal of Construction Procurement 2(1) 41-55.

HIGGIN, J., JESSOP, N. (1965) Communications in the Building Industry, Tavistock, London.

HEGAZY, T., ZANELDIN, E., GRIERSON, D. (2001) Improving Design Coordination for Building Projects I: Information Model, Journal of Construction Engineering and Management 127(4) 322-9.

HONG, Y., CHAN, D., CHAN, A., YEUNG, J. (2012) Critical Analysis of Partnering Research Trend in Construction Journals, Journal of Management in Engineering 28(2) 82-95.

IMAI, M. (1986) Kaizen: The Key to Japan's Competitive Success, McGraw-Hill, New York.

KLINE, P. (1994) An Easy Guide to Factor Analysis, Routledge, New York.

LAWRENCE, P.R., LORSCH, J.W. (1967) Differentiation and Integration in Complex Organizations, Administrative Science Quarterly 12(1) 1-47. 
LIU, A.M., FELLOWS, R. (2001) An Eastern Perspective on Partnering, Engineering, Construction and Architectural Management 8(1) 9-19.

LUCK, R. (1996) Construction Project Integration Strategies, EPSRC/IMI Partnering and Supply Chain Management Seminar, Salford, UK; 72-87.

MALONE, T.W., CROWSTON, K. (1994) The Interdisciplinary Study of Coordination, ACM Computing Surveys 26(1) 87-119.

MOHR, J., SPEKMAN, R. (1994) Characteristics of Partnering Success: Partnering Attributes, Communication Behaviour and Conflict Resolution Techniques, Strategic Management Journal 15(2) 135-52.

MOKHTAR, A., BEDARD, C., FAZIO, P. (1998) Information Model for Managing Design Changes in a Collaborative Environment, Journal of Computing in Civil Engineering 12(2) 82-92.

MOORE, C., MOSLEY, D., SLAGLE, M. (1992) Partnering: Guidelines for Win-Win Project Management, Project Management Journal 23(1) 1821.

NORUSIS, M.J. (1993) SPSS for Windows, Professional Statistics, Release 6.0, Statistical Package for Social Sciences, Chicago.

NYSTRÖM, J. (2005) The Definition of Partnering as a Wittgenstein Family Resemblance Concept, Construction Management and Economics 23(5) 473-81.

OWEN, R., ed. (2012) Integrated Design and Delivery Solutions, CIB White Paper on IDDS, CIB Publication 328, Rotterdam.

QUINN, R.W., DUTTON, J.E. (2005) Coordination as Energy-inConversation, Academy of Management Review 30(1) 36-57.

RACKHAM, N., FRIEDMAN, L., RUFF, R. (1996) Getting Partnering Right: How Market Leaders Are Creating Long-term Competitive Advantage, McGraw-Hill, New York.

RONCO, W.C., RONCO, J.S. (1996) Partnering Manual for Design and Construction, McGraw-Hill, New York.

SAAVEDRA, R., EARLY, P.C., VAN DYNE, L. (1993) Complex Interdependence in Task-Performing Groups, Journal of Applied Psychology 78(1) 61-72.

SARAM, D.D., AHMED, S.M. (2001) Construction Coordination Activities: What is Important and What Consumes Time, Journal of Management in Engineering 17(4) 202-13.

SPSS 15 (2007) Statistical Package for the Social Sciences 15, IBM Inc.

STEINS, G. (2000) Motivation in Person Perception: Role of the Other's Perspective, The Journal of Social Psychology 140(6) 692-709.

TANG, W., DUFFIELD, C.F., YOUNG, D.M. (2006) Partnering Mechanism in Construction: an Empirical Study on the Chinese Construction Industry, Journal of Construction Engineering and Management 132(3) 217-29.

TILLEY, P., BARTON, R. (1997) Design and Documentation Deficiency Causes and Effects, Proceedings of the First International Conference of Construction Process Reengineering, Gold Coast, Australia; 703-12. 
VAN DER MERWE, F.J., BASSON, G.A.J. (2013) Partnering within the Design Team, Fifth Post Graduate Conference on Construction Industry Development, Abstracts and Proceedings (16-18 March 2008) eds. J.J.P. Verster, H.J. Marx, Bloemfontein, South Africa; 261-70. [http://www.cib2007.com/papers/CIDB2008\%20Final\%20 Paper\%20No\%2012.pdf] Access Date (08.04.2013).

VARGO, S., LUSCH, R. (2008) Service-Dominant Logic: Continuing the Evolution, Journal of the Academy of Marketing Science 36(1) 1-10.

WEICK, K.E., SUTCLIFFE, K.M., OBSTFELD, D. (2005) Organizing and the Process of Sensemaking, Organization Science 16(4) 409-21.

WAGEMAN, R. (1995) Interdependence and Group Effectiveness, Administrative Science Quarterly 40(1) 145-80.

WEINGARDT, R.G. (1996) Partnering: Building a Stronger Design Team, Journal of Architectural Engineering 2(2) 49-54.

YUAN, M., ZHANG, X., CHEN, Z., VOGEL, D.R., CHU, X. (2009) Antecedents of Coordination Effectiveness of Software Developer Dyads from Interacting Teams: an Empirical Investigation, Engineering Management IEEE Transaction 56(3) 494-507.

ZANELDIN, E., HEGAZY, T., GRIERSON, D. (2001) Improving Design Coordination for Building Projects II: A Collaborative System, Journal of Construction Engineering and Management 127(4) 330-6.

Alındı: 18.06.2014; Son Metin: 01.10.2015

Anahtar Kelimeler: Ortaklık; tasarım süreci; başarı etkenleri; faktör analizi; çoklu regresyon analizi.

\section{BİNA TASARIM SÜRECİNDE ORTAKLIĞIN CAN ALICI BAŞARI ETKENLERI}

Etkin olamayan ortaklıklar bina projelerinin yönetiminde, tasarım tekrarlarına ve pahalı değişikliklere sebep olmaktadır. Ortaklığın etkileri, bina projesinin yapım evresi bağlamında etraflıca tartışılmaktadır; ancak tasarım evresi için çok nadir ele alınmaktadır. Bina tasarım sürecinin çokdisiplinli ve işbirlikçi yapısı göz önüne alındığında tasarım evresindeki ortaklığın uygulanabilirliğini, faydasını ve niteliğini inceleyen sistematik ve derin araştırmaya ihtiyaç duyulmaktadır. Bu çalışma, bina tasarım sürecindeki ortaklığın önemli başarı etkenlerinin belirlenmesi konusuna odaklanmaktadır ve mimarların bakış açısını yansıtmaktadır. Seçilen mimarlara bir anket uygulanmış ve toplanan veri, faktör analizi ile çoklu regresyon çözümlemesine tabii tutulmuştur. Faktör analizi yedi önemli başarı etkeni ortaya koymuştur: (1) Etkin iletişim; (2) etkin eşgüdüm; (3) karşılıklı amaçlar; 4) ortak hedefler; (5) uzun vadeli ilişkiler; (6) karşılıklı güven; ve (7) yönetimin desteği. Çoklu regresyon çözümlemesi, mimarların, tasarım projesinin teknik bağlılığını güçlü bir şekilde vurguladığını ve etkin eşgüdüm aradığını; mimarların, tüm paydaşların ortak hedeflere tam adanmışlığını takdir ettiğini; ve son olarak mimarların, bina tasarım sürecinde işbirliğini cesaretlendirecek uzun vadeli ilişkilere adanmışlık istediğini ortaya çıkarmıştır. Araştırma sonuçları, Bütünleşik Proje Teslim (BPT) sisteminin temel ilkeleri olan etkin eşgüdüm, karşılıklı kabul edilen ortak hedeflerin izlenmesi ve uzun vadeli ilişkiler kurulması esaslarını desteklemektedir. 
SEVGİ ZEYNEP DOĞAN; B.Arch., M.Sc., Ph.D.

Received her B.Arch., (1999), M.Sc., (2000) from Middle East Technical University; and Ph.D., (2005) from İzmir Institute of Technology (IYTE). Worked as a research associate at Illinois Institute of Technology and University of Nebraska. Currently Assistant Professor at IYTE. Research interests include social network analysis and machine learning techniques. sevgidogan@iyte.edu.tr.

PINAR KILIÇ ÇALĞICI; B.Arch., M.Sc.

Received her B.Arch. (2007) from Trakya University Faculty of Architecture and her M.Arch. (2010) from İzmir Institute of Technology. Currently works as a Research Assistant at İzmir Institute of Technology Department of Architecture and pursues her Ph.D. Research interests include art spaces, socio-cultural studies and environmental psychology. pinarkilic@iyte.edu.tr.

DAVID ARDITI; B.Sc., M.Sc., Ph.D.

Received his B.Sc. and M.Sc. in civil engineering from Middle East Technical University. Earned his Ph.D. in construction management from Loughborough University. Currently Professor at Illinois Institute of Technology. Founder and Director of the Construction Engineering and Management Program. Expertise includes all aspects of construction management, engineering and support. arditi@iit.edu.

HÜSNÜ MURAT GÜNAYDIN; B.Arch., M.Sc., Ph.D.

Received his B.Arch. (2007) from Ylld1z Technical University Faculty of Architecture. Earned his M.Sc., and Ph.D. in civil engineering from Illinois Institute of Technology. Currently works as a Professor at İstanbul Technical University. Research interests include project management and construction technologies. gunaydinh@itu.edu.tr. 